\title{
IN VITRO ANTIOXIDANT ACTIVITY OF BARK EXTRACTS OF OROXYLUM INDICUM (L) VENT
}

\section{PRIYANKA SAHA, PRAKASH ROY CHOUDHURY, SUBRATA DAS, ANUPAM DAS TALUKDAR*, MANABENDRA DUTTA CHOUDHURY}

Department of Life Science and Bioinformatics, Ethnobotany \& Medicinal Plant Research Laboratory, Assam University, Silchar - 788 011, Assam, India. Email: anupam@bioinfoaus.ac.in

Received: 06 April 2017, Revised and Accepted: 10 May 2017

ABSTRACT

Objectives: The aim of the present work is to screen the antioxidant potentiality of the bark extract of Oroxylum indicum (L) Vent, ethnomedicinally prescribed plant as hepatoprotective.

Methods: Bark extracts were prepared using soxhlet apparatus. Total phenol, flavonoid, and total alkaloid were analyzed using Folin-Ciocalteu assay, aluminum chloride colorimetric assay, atropine standard, respectively. Antioxidant capacity and free radical scavenging potentialities were done by several in vitro methods, viz.; 1,1-diphenyl-2-picrylhydrazyl (DPPH), hydrogen peroxide scavenging activity, reducing power assay, metal chelating activity, ferric reducing ability of plasma (FRAP) assay, and thiobarbituric acid (TBA) method.

Result: Total phenol, flavonoid, and alkaloid were found to be highest in methanolic extract of 0 . indicum (L) Vent. Methanolic extract of the bark showed very low inhibitory concentration $\left(\mathrm{IC}_{50}\right)$ and effective concentration values for DPPH assay and reducing power assay compared to another extract. In hydrogen peroxide scavenging activity assay, the lowest $\mathrm{IC}_{50}$ value was recorded in methanolic extract with $153.45 \pm 0.06 \mu \mathrm{g} / \mathrm{ml}$. The FRAP assay for 0 . indicum methanolic extract showed the highest activity at $940.09 \pm 0.07 \mu \mathrm{g} / \mathrm{mL}$ of ascorbic acid equivalent. The ferric reducing capacity and TBA values of the plant extracts confirmed the presence antioxidant principles in the bark of the said plant.

Conclusion: These underused plants may be used for mitigating the detrimental effect of oxidative stress and reactive oxygen species-mediated disease and thus justifies its use in folklore medicines.

Keywords: Antioxidant, Free radical, Oxidative stress, Phenols, Flavonoids, Alkaloids, Oroxylum indicum (L) Vent.

(C) 2017 The Authors. Published by Innovare Academic Sciences Pvt Ltd. This is an open access article under the CC BY license (http://creativecommons. org/licenses/by/4. 0/) DOI: http://dx.doi.org/10.22159/ajpcr.2017.v10i8.18977

\section{INTRODUCTION}

Antioxidants are composites that protect cells against free intermediated processes. Reactive oxygen intermediates or free radicals, products of oxidative stress, are responsible for tissue damage of living system, in aging and the pathogenesis of diseases such as arthritis, atherosclerosis, diabetes, and cancer [1-4]. Several studies explained plants as natural antioxidant sources due, mainly, to the presence of flavonoids, which act in decreasing free radical formation and also in foraging free radicals [5-7]. Phytochemicals, belonging to several chemical groups in various plants, are drawing the attention of scientist to find more effective antioxidants from plant species.

Oroxylum indicum (L) Vent. important medicinal plant is locally known as Shonapatha in Bengali language in Southern Assam of India. This plant mostly occurs in Japan, China, Bangladesh, and Malaysia. In India, it is found in Western, Southern, and North East region up to an altitude of $1200 \mathrm{~m}$ and found mainly in ravine and moist places in forests. The use of this plant for various ailments is part of traditional folklore of various communities in Manipur (India) such as Anal, Kuki, Mao, Maram, Tanghkul, and Zeliangrong. The traditional knowledge of Maram Naga village of Senapati district, Manipur, reveals that the decoction of $O$. indicum bark can be used as a potent anticancer medicine, especially against nasopharyngeal cancer [8,9]. Stem bark is used to treat bile problems gastric and liver disorder including hepatic cancer [10]. The fruits of this plant are used among Mao tribe as an expectorant which improves the appetite [11-14]. Leaves of this plant are prescribed in snake bite and liver disorders such as jaundice $[13,14]$. Many phytochemical such as biochanin A possesses antifungal action and tumor necrosis factor $\alpha$ [12]. Ellagic acid is another important polyphenolic compound found in the leaves of this plant [15]. O. indicum leaves also reported to have a beneficial effect on enlarged spleen, headaches, gastric, and hepatic ulcers [12]. A few apparent preliminary antioxidant studies of $O$. indicum have been undertaken $[15,16]$, but a detailed report on antioxidant efficacy of the plant is still to be evaluated. The present work was conducted to understand and focus on evaluating the comparative antioxidant property of bark extracts.

\section{METHODS}

\section{Collection of plant material}

The bark of plant was collected from Southern Assam of Cachar District (Northeast India). It was identified and submitted in Assam University Herbaria with voucher specimen no. 2578. After proper washing, the dried parts of the plant were pulverized separately into fine powder and were used for preparation of extracts.

\section{Chemicals and equipment}

All chemicals used were of analytical reagent grade. Ascorbic acid, atropine, gallic acid, t-butylhydroxyanisole, aluminum chloride Folin-Ciocateu reagent, ammonium thiocyanate, disodium phosphate, monosodium dihydrogen phosphate, trichloroacetic acid, hydrogen peroxide, iron (III) chloride, and iron(II) chloride were purchased from Merck Chemicals (Mumbai); and 2,2-diphenyl-1-picrylhydrazyl (DPPH), ascorbic acid, glacial acetic acid and tripyridyl-striazine (TPTZ) were purchased from Himedia Laboratories (Mumbai). Absorbances were taken using ultraviolet visible spectrophotometer (Labomed, Inc., USA). Other chemicals and solvents were purchased from Merck Chemicals, Mumbai, India.

\section{Preparation of extracts}

About $50 \mathrm{~g}$ of powdered bark samples of both the plants were used for extraction by Soxhlet system using different solvents, viz.; hexane, ethyl 
acetate, acetone, and methanol. The filtrates were concentrated under reduced pressure by a rotatory evaporator. The resulting residue was then filtered and stored at $4^{\circ} \mathrm{C}$ for further antioxidant assays.

\section{Quantitative phytochemical analysis}

Quantitative phytochemical assays were performed with focus on testing different chemical groups present in different solvent extracts of 0 . indicum.

\section{Determination of phenols}

Total phenolic constituent of the extracts was determined with standard protocol [17]. $1 \mathrm{ml}$ of $2000 \mu \mathrm{g}$ extract solution was added to a volumetric flask. $45 \mathrm{ml}$ distilled water and $1 \mathrm{ml}$ Folin-Ciocalteu reagents were then added and shaken vigorously. After 3 minutes, $3 \mathrm{ml}$ of $\mathrm{Na}_{2} \mathrm{CO}_{3}(2 \%)$ solution was added, and the mixture was allowed to stand for 2 hrs by intermittent shaking. Absorbance was measured at $760 \mathrm{~nm}$. Results were expressed in microgram gallic acid equivalent (GAE)/mg of plant extracts.

\section{Determination of flavonoids}

Total flavonoid content (TFC) was determined using the Dowd method [18]. $1 \mathrm{ml}$ of $2 \%$ aluminium trichloride $\left(\mathrm{AlCl}_{3}\right)$ was mixed in methanol with the same volume of the various extracts $(2000 \mu \mathrm{g})$. The absorbance was read at $415 \mathrm{~nm}$ after 10 minutes against blank consisting of $1 \mathrm{~mL}$ extract solution with $1 \mathrm{ml}$ methanol without $\mathrm{AlCl}_{3}$, and the flavonoid content was expressed as microgram quercetin equivalent/mg of plant extract.

\section{Determination of alkaloids}

A part of dried solvent extract was dissolved in 2N HCL and then filtered. $1 \mathrm{ml}$ of filtrate was washed with $10 \mathrm{ml}$ chloroform in a separatory funnel. The $\mathrm{pH}$ of this solution was then adjusted to neutral with $0.1 \mathrm{~N}$ $\mathrm{NaOH} .5 \mathrm{ml}$ of BCG solution, and $5 \mathrm{ml}$ of phosphate buffer were added. The mixture was extracted with chloroform by shaking; the extracted mixture was then diluted with chloroform [19]. The absorbance was measured at spectrum of $470 \mathrm{~nm}$, and the result was expressed as microgram atropine equivalent/mg of plant extract.

\section{In vitro antioxidant assays}

\section{Determination of DPPH free-radical scavenging activity}

The free radical scavenging activity of the plant extracts was measured using DPPH by the method of Kumarasamy et al. [20] $80 \mu \mathrm{g} / \mathrm{ml} \mathrm{DPPH}$ was prepared with methanol. Serial dilutions were carried out with the $1 \mathrm{mg} / \mathrm{ml}$ stock solutions of the extracts. $2 \mathrm{ml}$ of each solution was then mixed with $2 \mathrm{ml}$ of DPPH and allowed to stand for 30 minutes; the absorbance was then read at $517 \mathrm{~nm}$. Ascorbic acid was used as standard. $\mathrm{IC}_{50}$ value was also calculated using a concentration-response curve. Inhibition of DPPH free radical in percentage was calculated by formula:

DPPH radical scavenging activity $(\%)=($ A control-A test $) / A$ control $\times 100$

\section{Reducing power assay}

The reducing power assay was conducted according to the method of Oyaizu [21]. To $2.5 \mathrm{~mL}(1 \mathrm{mg} / \mathrm{mL})$ of a plant extract, $2.5 \mathrm{~mL}$ of $0.2 \mathrm{~mol} / \mathrm{L}$ sodium phosphate buffer and $2.5 \mathrm{~mL}$ of $1 \%$ potassium ferricyanide were mixed. After incubating the mixture at $50^{\circ} \mathrm{C}$ for 20 minutes, $2.5 \mathrm{~mL}$ trichloroacetic acid solution was added, and the mixture was centrifuged at $650 \mathrm{rpm}$ and $25^{\circ} \mathrm{C}$ for 10 minutes. The supernatant $(5 \mathrm{ml})$ was mixed with $5 \mathrm{ml}$ distilled water and $1 \mathrm{~mL}$ ferric chloride solution. The absorbance was measured at $700 \mathrm{~nm}$. Ascorbic acid was used as standard.

\section{Hydrogen peroxide scavenging assay}

Hydrogen peroxide scavenging potential of the plant extract was determined using the method described by Jayaprakasha et al. [22]. A solution of hydrogen peroxide $(20 \mathrm{mM})$ was prepared in (phosphate buffer saline [PBS], pH 7.4). Different concentrations of the extract $(20-100 \mu \mathrm{g} / \mathrm{ml})$ in ethanol $(1 \mathrm{ml})$ were added to $2 \mathrm{ml}$ of hydrogen peroxide solution in PBS. After 10 minutes the absorbance was measured at $230 \mathrm{~nm}$ against blank solution that contained hydrogen peroxide solution without the extract. The percentage of $\mathrm{H}_{2} \mathrm{O}_{2}$ scavenging of the plant extract was calculated as follows:

$\%$ Scavenged $\left[\mathrm{H}_{2} \mathrm{O}_{2}\right]=[($ Abs control - Abs sample $) /$ Abs control $] \times 100$

\section{Ferric reducing antioxidant power (FRAP) assay}

The antioxidant activity analysis using FRAP was performed according to the method reported by Benzie and Strain [23]. The stock solutions included $300 \mathrm{mM}$ acetate buffer $\mathrm{pH}$ 3.6, $10 \mathrm{mM}$ TPTZ solution in $40 \mathrm{mM} \mathrm{HCl}$, and $20 \mathrm{mM} \mathrm{FeCl} 3.6 \mathrm{H}_{2} \mathrm{O}$ solution. The fresh working solution was prepared by mixing $25 \mathrm{ml}$ acetate buffer, $2.5 \mathrm{ml}$ TPTZ, and $2.5 \mathrm{ml}$ $\mathrm{FeCl}_{3} \cdot 6 \mathrm{H}_{2} \mathrm{O}$. The temperature of the solution was raised to $37^{\circ} \mathrm{C}$ before use. Various solvent extracts $(200 \mu \mathrm{l})$ were allowed to react with $2800 \mu \mathrm{l}$ of the FRAP solution for 30 minutes in the dark condition. Readings of the colored product (ferrous-tripyridyltriazine complex) were taken at $593 \mathrm{~nm}$. The FRAP values of samples were expressed as $\mu \mathrm{g} / \mathrm{mL}$ of ascorbic acid equivalent (AAE).

\section{Measurement of ferrous ion chelating ability}

The chelating ion by various plant extracts from the bark of $O$. indicum was measured by the method of Yan et al., [24]. Various concentrations of the solvent extracts such as, 50,100,150,200,250, and $300 \mu \mathrm{g} / \mathrm{mL}$ of O. indicum were added with $1 \mathrm{~mL}$ of $2 \mathrm{mM} \mathrm{FeCl}_{2}$ separately. The reaction was initiated by the addition of $5 \mathrm{mM}$ ferrozine $(1 \mathrm{~mL})$. Absorbance was measured at $562 \mathrm{~nm}$ after 10 minutes ascorbic acid was used as standard.

$$
\text { Chelating activity }(\%)=\frac{\text { Control OD }- \text { Sample OD }}{\text { Control OD }} \times 100
$$

\section{Thiobarbituric acid (TBA) method}

This assay was performed according to the method reported by Kikuzaki and Nakatani [25]. $2 \mathrm{ml}$ of $20 \%$ trichloroacetic acid and $2 \mathrm{ml}$ of $0.67 \%$ of TBA were added to $1 \mathrm{ml}$ of the sample solution. The mixture was placed in a boiling water bath for 10 minutes and then centrifuged at $3000 \mathrm{rpm}$ for 20 minutes. The absorbance of the supernatant was measured at $552 \mathrm{~nm}$. The inhibition rate was calculated using the following equation:

$[(\mathrm{Ac}-\mathrm{As}) / \mathrm{Ac}] \times 100$, where Ac is the absorbance of the control and As is the absorbance of the sample.

\section{RESULTS}

Total phenolic (TPC), TFC, alkaloid content (TAC) of the extract In this study, $O$. indicum was recorded to possess highest phenolic, alkaloid, and flavonoid content in the methanolic extract with $118.84 \pm 0.62 \mu \mathrm{g}$ GAEs/mg of extract, $81.42 \pm 0.62 \mu \mathrm{g}$ quercetin $/ \mathrm{mg}$ of extract, $111.66 \pm 0.01 \mu \mathrm{g}$ atropine $/ \mathrm{mg}$ of extract, respectively. TPC was calculated using the standard curve of gallic acid (standard equation curve equation: $Y=0.0033 x+0.0378, R^{2}=0.9761$ ), $T F C$ was calculated using the standard curve of quercetin (standard equation curve equation: $\left.Y=0.03576 \mathrm{x}+0.211, \mathrm{R}^{2}=0.9922\right)$, and $\mathrm{TAC}$ was calculated using the standard curve of atropine (standard equation curve equation: $\mathrm{Y}=0.0003 \mathrm{x}+0.0052, \mathrm{R}^{2}=0.9862$ )

\section{DPPH radical scavenging assay}

The results of DPPH radical scavenging activity of 0 . indicum bark extract and the standard ascorbic acid $\left(\mathrm{IC}_{50}=12.25 \pm 0.01 \mu \mathrm{g} / \mathrm{ml}\right)$ are presented in Table 1 . The $50 \%$ inhibitory activity has been widely studied as a parameter to measure antioxidant activity. In this study, both the plant extract and the standard significantly scavenged the DPPH radical with increasing concentrations. Fig. 1 showed the dose response curve of DPPH radical scavenging activity. $\mathrm{IC}_{50}$ of the methanolic extract $(9.42 \pm 0.04 \mu \mathrm{g} / \mathrm{ml})$ was found to be lowest than all another sample extract. However, with the addition of a larger amount of bark extract of both plants to the DPPH assay mixture, the degree of inhibition decreased, indicating a prooxidant effect. 
Table 1: TPC, TFC, and TAC estimation of various extracts of $O$. indicum

\begin{tabular}{llll}
\hline Sample extract & $\begin{array}{l}\text { TPC ( } \boldsymbol{\mu g} \text { GAEs/mg of extract) total } \\
\text { mg of extract) }\end{array}$ & $\begin{array}{l}\text { TFC ( } \boldsymbol{\mu g} \text { Quercetin/mg of extract) total } \\
\mathbf{m g} \text { of exact) }\end{array}$ & TAC ( $\boldsymbol{\mu g}$ atropine/mg of extract) \\
\hline Hexane & $16.72 \pm 0.03$ & $0.098 \pm 0.07$ & $34.33 \pm 0.08$ \\
Ethyl acetate & $76.72 \pm 0.03$ & $76.70 \pm 0.03$ & $38.00 \pm 0.02$ \\
Acetone & $02.18 \pm 0.01$ & $54.00 \pm 0.01$ & $93.32 \pm 0.06$ \\
Methanol & $118.84 \pm 0.62$ & $81.42 \pm 0.62$ & $111.66 \pm 0.01$ \\
\hline TPC: Total phenolic content, TFC: Total flavonoid content, TAC: Total alkaloid contents. Values are expressed as mean $\pm S D, n=3$ sets in each group. Mean values followed
\end{tabular}

in a column are significantly different $(\mathrm{p}<0.05), \mathrm{SD}$ : Standard deviation, O. indicum: Oroxylum indicum

\section{Reducing power assay and FRAP assay}

As shown in Fig. 2, various extracts exhibited a dose-dependent increase in the ferric ion reducing potential. The lowest effective concentration $\left(\mathrm{EC}_{50}\right)$ was recorded in the methanolic extract with $292.31 \pm 0.06 \mu \mathrm{g} / \mathrm{ml}$ which was much higher than the $\mathrm{EC}_{50}$ of the standard, ascorbic acid $(910.37 \mu \mathrm{g} / \mathrm{ml})$. A detailed $\mathrm{EC}_{50}$ of various extracts and FRAP value of both the plant is depicted in Fig. 2. The FRAP values (Fig. 1) ranged from 324.55 to $967.12 \mu \mathrm{g} / \mathrm{mL}$ AAE for various fractions of the plant.

\section{Hydrogen peroxide scavenging activity}

As shown in Fig. 1, 0. indicum also demonstrated hydrogen peroxide decomposition activity in a concentration dependent manner with lowest IC $_{50}$ exhibited by methanolic extract ( $\mathrm{IC}_{50}=153.45 \mu \mathrm{g} / \mathrm{ml}$ ) which was much lower than standard ascorbic acid, $\mathrm{IC}_{50}=228.97 \mu \mathrm{g} / \mathrm{ml}$.

\section{Metal chelating activity and TBA assay}

As observed in DPPH and hydroxyl radical scavenging assays, the percentage of metal chelating activity was determined to be sample concentration dependent and it was increasing with the increase in the concentration of extract from 50 to $300 \mu \mathrm{g} / \mathrm{mL}$. The percentage of inhibition of the metal chelation was varying from $35.77 \%$ to $37.53 \%$ (in $50 \mu \mathrm{g} / \mathrm{mL}$ of extract) to $80.19-87.41 \%$ (in $300 \mu \mathrm{g} / \mathrm{mL}$ extract). The $\mathrm{IC}_{50}$ value of the methanolic bark extract was highest with $121.54 \mu \mathrm{g} / \mathrm{ml}$. The percentage of inhibition of free radicals by various concentrations of methanol samples was more or less to that of the respective concentration of the standard drug, ascorbic acid.

Result of TBA assay depicted the radical scavenging activity of various extracts of the plant where the $\mathrm{IC}_{50}$ values of methanolic extract of O. indicum $(18.9788 \mu \mathrm{g} / \mathrm{ml})$ where significantly more than ascorbic acid $\left(\mathrm{IC}_{50}=35.77 \mu \mathrm{g} / \mathrm{ml}\right.$, taken as standard.

\section{Inhibitory concentration $\left(\mathrm{IC}_{50}\right)$}

$\mathrm{IC}_{50}$ values of various bark extracts of $O$. indicum and standard ascorbic acid, BHT, Quercetin for DPPH, $\mathrm{H}_{2} \mathrm{O}_{2}$ radical scavenging activity, ferrous chelating activity, TBA are depicted in Fig. 1.

\section{DISCUSSION}

Highest phenolic and flavonoid content were recorded in methanolic extract of $O$. indicum, while hexane extract showed least. To understand the noticeable free radical scavenging activity of assigned extracts, DPPH assay was performed. As the maximum radical scavenging activity was exhibited by the methanolic extract, thus it is implying a positive correlation of both the phenol and flavonoid content to the antioxidant activity of a plant [26-29]. This activity was cross-validated by performing reducing power assay, $\mathrm{H}_{2} \mathrm{O}_{2}$ scavenging activity, FRAP assay, metal chelating activity, and TBA assay with all the extracts. For each individual assay, methanolic extract exhibited similar antioxidant efficacy. Furthermore, methanolic extract of $O$. indicum exhibited the higher antioxidant activity in comparison to the positive control. This finding invariably authenticates the antioxidant potential of $O$. indicum in general and methanolic extract in particular. Compounds such as biochanin A, bhrysin, baicalein, oroxylin A, dihydrobaicalein, $\beta$-sitosterol, iso-flavone, and prunetin present in the bark may have contributed to this activity [29].

Highest alkaloid content was noted in methanolic extract than other extracts used. Interestingly above extracts also showed highest

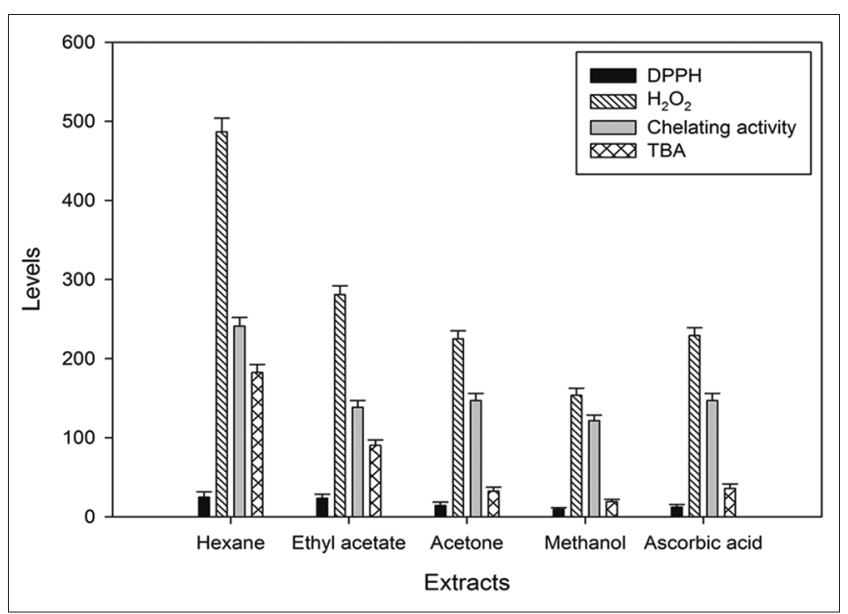

Fig. 1: DPPH radical scavenging activity, $\mathrm{H}_{2} \mathrm{O}_{2}$, chelating activity and TBA activity of the various bark extracts of $O$. indicum in comparison with ascorbic acid

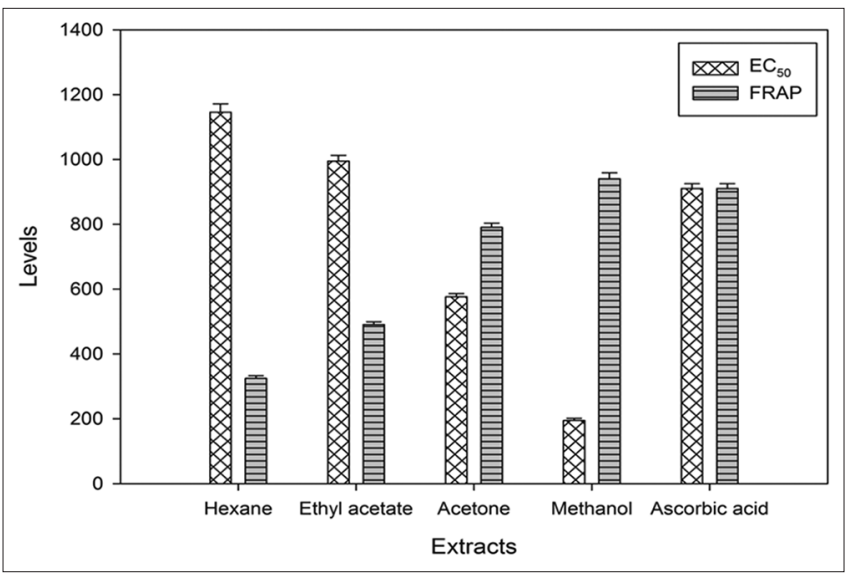

Fig. 2: Comparison of effective concentration and FRAP values of various fractions of bark parts of $O$. indicum

antioxidant activity than others. Although the general concept is that among all chemical groups, flavonoids and phenols are the major groups responsible for antioxidant-oxidant activity; our study proposes a direct correlation between alkaloid content and antioxidant activity of plants. While working with Turkish Tea polyphenols and alkaloid Erol et al. [30] proposed that alkaloid content is linked with antioxidant activity. Rackova et al. [31-33] suggested that probably high lipophilicity of the alkaloids is responsible for antiradical reactivity.

\section{CONCLUSION}

The study suggests that methanolic extract from $O$. indicum bark are a rich source of antioxidants. Experimental evidence pointing $O$. indicum a promising sources of active principles. Further detailed in-vivo experiments can establish its efficacy in this regard. 


\section{ACKNOWLEDGMENTS}

The authors are grateful to DBT (Government of India) Sponsored Bioinformatics Infrastructure Facility (BIF) of Assam University and Delcon's e-Journal Access Facility.

\section{REFERENCES}

1. Ames BM. Dietary carcinogens and anticarcinogens: Oxygen radical and degenerative diseases. Science 1983;221(4617):1256-63.

2. Feher J, Csomos G, Vereckei A. Free Radical Reactions in Medicine. Berlin, Heidelberg: Springer-Verlag; 1987. p. 40-43.

3. Aruoma OI. Free radicals, oxidative stress and antioxidants in human health. J Am Oil Chem Soc 1998;75(2):199-212.

4. Halliwel BG, Gutteridge JM. Free Radicals in Biology and Medicine. Oxford: Clarendon Press; 1989. p. 416-94.

5. Miller AL. Antioxidant flavonoids: Structure, function and clinical usage. Altern Med Rev 1996;1(2):103-11.

6. Pietta PG. Flavonoids as antioxidants. J Nat Prod 2000;63(7):1035-42.

7. Knekt P, Kumpulainen J, Järvinen R, Rissanen H, Heliövaara M, Reunanen A, et al. Flavonoid intake and risk of chronic diseases. Am J Clin Nutr 2002;76(3):560-8.

8. Kumar KR, Ved DK. 100 Red Listed Medicinal Plants of Conservation Concern in Southern India. Bangalore, India: Foundation for Revitalisation of Local Health Traditions; 2000. p. 1-467.

9. Mao AA. Oroxylum indicum Vent. - A potential anticancer medicinal plant. Ind J Tradit Knowl 2002;1(1):17-21.

10. Kunwar RM, Uprety Y, Burlakoti C, Chowdhary CL, Bussmann RW. Indigenous use and ethnopharmacology of medicinal plants in Far-West Nepal. Ethnobot Res Appl 2009;7:5-28

11. Chopra RN, Nayar SL, Chopra IC. Glossary of Indian Medicinal Plants. New Delhi: National Institute of Science Communication and Information Resources; 2002. p. 182.

12. Drury CH. Ayurvedic Useful Plants of India. New Delhi: Asiatic Publishing House; 2006. p. 360.

13. Nadkarni AK. Indian Materia Medica. Mumbai: Bombay Popular Prakashan; 1982. p. 876-7.

14. Khare CP. Indian Medicinal Plants. New York: Springer Science Business Media, LLC; 2007. p. 453.

15. Singh D, Moirangthem DS, Talukdar NC, Bora U, Kasoju N, Das RK. Differential effects of Oroxylum indicum bark extracts: Antioxidant, antimicrobial, cytotoxic and apoptotic study. Cytotechnology 2013;65(1):83-95

16. Kalaivani T, Mathew L. Phytochemistry and free radical scavenging activities of Oroxylum indicum. Environ Int J Sci Technol 2009;4:45-52.

17. Slinkard K, Singleton VL. Total phenol analyses: Automation and comparison with manual methods. Am J Enol Vitic 1997;28:49-55. Available from: http://www.ajevonline.org/content/28/1/49.short.

18. Arvouet-Grand A, Vennat B, Pourrat A, Legret P. Standardisation d'un extrait de propolis et identification des principaux constituants. J Pharm Belgique 1994;49:462-8. Available from: https://www.ncbi.nlm.nih. gov/pubmed/788463
19. Ajanal M, Gundkalle MB, Nayak SU. Estimation of total alkaloid in Chitrakadi Vati by UV-spectrophotometer. Anc Sci Life 2012;31:198201. Available from: https://www.ncbi.nlm.nih.gov/pmc/articles/ PMC3644759.

20. Kumarasamy Y, Byres M, Cox PJ, Jaspars M, Nahar L, Sarker SD. Screening seeds of some Scottish plants for free radical scavenging activity. Phytother Res 2007;21(7):615-21

21. Oyaizu M. Antioxidative activities of browning reaction prepared from glucosamine. Jpn J Nutr 1986;44:307-15. Available from: https://www. jstage.jst.go.jp/article/eiyogakuzashi1941/44/6/44 6 307/ article.

22. Jayaprakasha GK, Jaganmohan Rao L, Sakariah KK. Antioxidant activities of flavidin in different in vitro model systems. Bioorg Med Chem 2004;12(19):5141-6.

23. Benzie IF, Strain JJ. The ferric reducing ability of plasma (FRAP) as a measure of "antioxidant power": The FRAP assay. Anal Biochem 1996;239(1):70-6

24. Yan LY, Teng LT, Jhi TJ. Antioxidant properties of Guava fruits: Comparison with some local fruits. Sunway Acad J 2006;3:9-20.

25. Kikuzaki H, Nakatani N. Antioxidant effects of some ginger constituents. J Food Sci 1993;58:1407-10. Available from: http://www. onlinelibrary.wiley.com/doi/10.1111/j.1365-2621.1993.tb06194.x/pdf.

26. Gheldof N, Engeseth NJ. Antioxidant capacity of honeys from various floral sources based on the determination of oxygen radical absorbance capacity and inhibition of in vitro lipoprotein oxidation in human serum samples. J Agric Food Chem 2002;50(10):3050-5.

27. Holasova M, Fiedlerova V, Smrcinova H, Orsak M, Lachman J, Vavreinova S. Buckwheat-the source of antioxidant activity in functional foods. Food Res Int 2002;35(23):207-11.

28. Aljadi AM, Kamaruddin MY. Evaluation of the phenolic contents and antioxidant capacities of two Malaysian floral honeys. Food Chem 2004;85(4):513-8. Available from: http:/www.sciencedirect.com/ science/article/pii/S0963996901001855.

29. Song FL, Gan RY, Zhang Y, Xiao Q, Kuang L, Li HB. Total phenolic contents and antioxidant capacities of selected Chinese medicinal plants. Int J Mol Sci 2010;11(6):2362-72

30. Erol N, Sari F, Velioglu Y. Polyphenols, alkaloids and antioxidant activity of different grades Turkish black tea. GIDA 2010;35(3):161-8. Available from: https:/www.ncbi.nlm.nih.gov/pmc/articles/ PMC2904921.

31. Racková L, Májeková M, Kost'álová D, Stefek M. Antiradical and antioxidant activities of alkaloids isolated from Mahonia aquifolium. Structural aspects. Bioorg Med Chem 2004;12(17):4709-15.

32. Parameshwar P, Reddy YN. Protective role, in vitro free radical scavenging activities of Alangium salvifolium (Linn) against $\mathrm{CCl}_{4}$ induced hepatic damage in rats. Int J Pharm Pharm Sci 2015;7(1):44752. Available from: http://www.innovareacademics.in/journals/index. php/ijpps/article/view/4480.

33. Meziti A, Bouriche H, Hiche M, Kada S, Senator A, Dimertas I. Antioxidant and anti-inflammatory activities of Rubus fruticosus and Zizyphus vulgaris methanol extracts. Int J Pharm Pharm Sci 2017;9(2):69-76. Available from: http://www.innovareacademics.in/ journals/index.php/ijpps/article/view/14374. 